\begin{tabular}{lllll}
\hline Estudios de Economía Aplicada & Vol. $36-1$ & 2018 & Págs. 277-290 \\
\hline
\end{tabular}

\title{
The Rise and Prospect of China's Economy*
}

\section{YANYUN ZHAO}

Renmin University of China, School of Statistics, Mingde Main Building, No.59, Zhongguancun Street, Haidian District, 100872 Beijing, P.R.China. E-mail: cas-kriu@ruc.edu.cn

\begin{abstract}
Since the reform and opening policy in 1978, China's economy has developed rapidly and made remarkable achievements. On the new historical starting point, this paper systematically reviews and summarizes the whole process of China's economic rise, by combining theoretical and empirical analysis, and provides the outlook of China's new economy. This article aims to grasp China's future position both at home and abroad, and strengthen the mutual promotion between China and the world.
\end{abstract}

Keywords: China's Economy, Rise, Prospect, Reform and Opening.

\section{El ascenso y la perspectiva de la economía de China}

\section{RESUMEN}

Desde la reforma y la política de apertura de 1978, la economía de China se ha desarrollado rápidamente y ha logrado logros notables. Sobre el nuevo punto de partida histórico, este artículo revisa y resume, de una manera sistemática, el proceso del crecimiento económico de China, combinando análisis teórico con el empírico, y proporciona una perspectiva de la nueva economía de China. Este artículo también aborda la posición futura de China tanto en el país como en el extranjero, así como pretende fortalecer la promoción mutua entre China y el mundo.

Palabras clave: Economía de China, crecimiento, perspectiva, reforma y apertura.

JEL Classification: A10, P20

\footnotetext{
* Acknowledgements: thanks to Prof. Guido Ferrari for useful suggestions and to WANG Kang, LI Qian, CHEN Anqi, LIU Bingjie, ZHAO Mingming, CHEN Bingwen, XING Chen and Su Wei, the Graduates of School of Statistics of Renmin University of China, for contributing to the preparation of this paper and for sorting out the literature.
}

Artículo recibido en octubre de 2017 y aceptado en noviembre de 2017

Artículo disponible en versión electrónica en la página www.revista-eea.net, ref. ə-36118 


\section{INTRODUCTION}

Great changes have taken place in China since the reform and opening. China has developed from a poor and backward agricultural country to a developed and modern industrial power. Chinese people moved from the period of solving the problem to take food and clothing, and ran into well-off society. China's economy has also evolved from planned economy to market economy. In 2002, we put forward the goal of "building a well-off society in an all-round way" to "completing the building of a well-off society in all respects" by 2020. (Figure 1 shows the change in China's gross domestic product (GDP) and its growth rate.)

Figure 1

Changes of China's GDP and its growth rate from 1953 to 2015
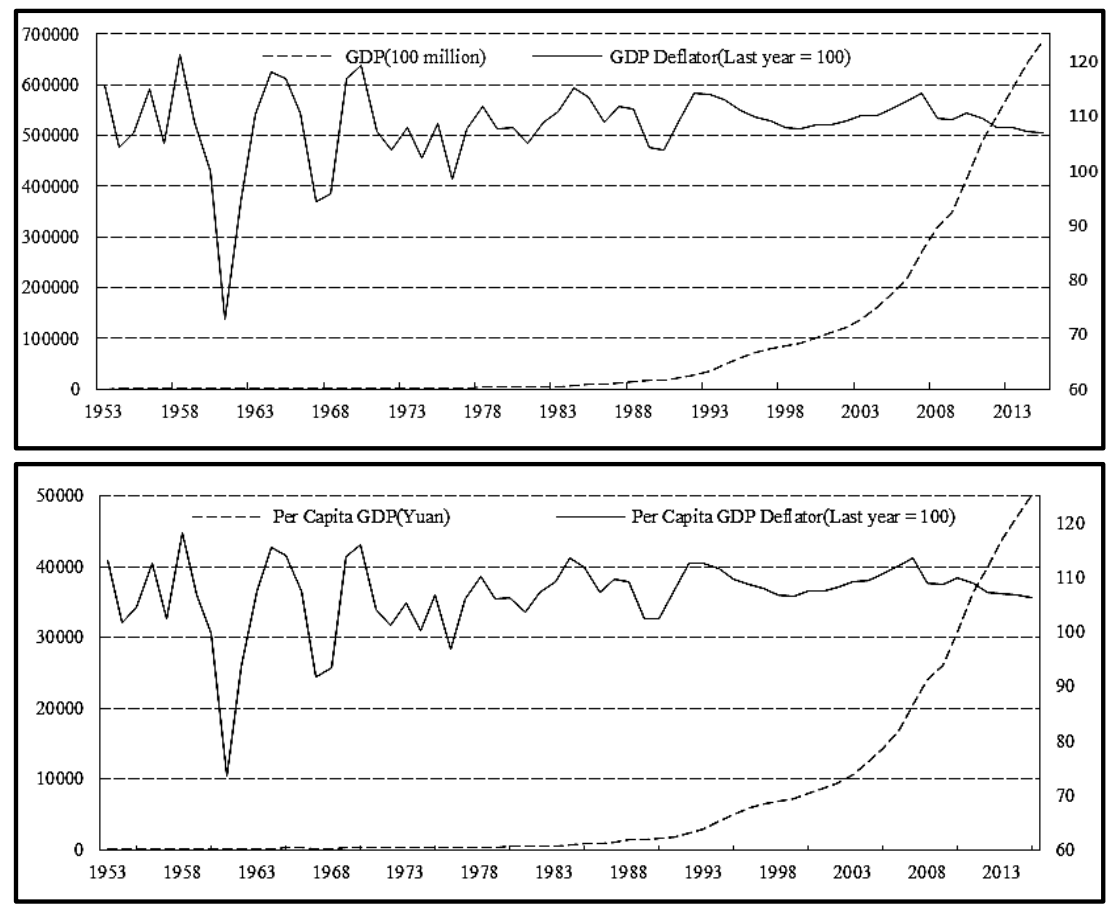

Data source: China statistical yearbook.

At the same time, since the accession to the WTO, China's foreign trade has developed rapidly, and the country has become the world's largest exporter and the second largest importer. The economic aggregate has also jumped from sixth to second place in the world. In recent years, the Chinese government takes the 
Supply-side Structural Reform $^{1}$ as the main line to accelerate economic restructuring and upgrading, cultivate new impetus of innovation driven development, thus improving both the quality and quantity of economic growth. This article will review the process of China's economic growth since the reform and opening, and provide the outlook of the future of China's economy at a new starting point. It also aims to grasp China's future position both at home and abroad from a historical perspective and increases the deep interaction between China and the world.

Based on previous research, this paper will deal with the following two points: first, standing at a new historical starting point, we will systematically review the whole process of China's economic growth since the reform and opening, and objectively forecast its future development; second, we use both theoretical and empirical analysis, and use the detailed data to demonstrate the rising process of China's economy. The results can serve as a powerful basis for looking into the future. Specifically, the first four parts of this article introduce the four stages of the rising process of China's economy respectively: the planning economy of China before 1978, the development of the reform and opening policy (19791992), the development in the economic transformation (1993-2001), the development in the upgrading industry (2001 - present). We will look into the prospects of China's new economy, and summarize the whole text in the last part.

\section{THE PLANNING ECONOMY OF CHINA BEFORE 1978}

When the People's Republic of China (PRC) was first established in October 1949, the level of China's economic development was very low. Many people engaged in agriculture, while industrial development was relatively backward. The per capita GDP was only a few hundred dollars and material needs of the people had not yet been effectively met. This period shows three characteristics: shortage of funds, limited products available for export and insufficient economic surplus (Zhao Lingyun, 2009). In this context, it’s a strategic choice for a backward country seeking development that China began to implement the planned economy.

During the planning economy period, the land reform and democratic reform were carried out around the whole country, as well as the socialist reform of the ownership of means of production. The pattern of agricultural production gradually changed from decentralized management to collectivized management. Peasants were organized in an orderly manner and formed a joint force to

\footnotetext{
${ }^{1}$ The supply-side structural reforms is for improving supply quality, promoting structural adjustment by way of reform, correcting factor allocation distortion, expanding the effective supply, improving the supply structure of the changing needs of adaptability and flexibility, improving the total factor productivity, so as to better meet the needs of the masses, and promote the sustained and healthy economic and social development.
} 
improve the efficiency of the use of production tools and agricultural productivity. China's grain output increased from 163.92 million tons in 1953 to 304.77 million tons in 1977 and cotton production increased from 1,304,000 tons to 2.167 million tons at the same time. The development of agriculture provided industry with ample raw materials and funds.

As an important development pattern for the formation of capital factors, the heavy industry oriented planned economy laid a solid foundation for the development of new China. During this period, China completed the initial capital accumulation from a backward agricultural country to an industrial country. And the central government could focus their efforts on setting up many key industrial projects rapidly. Some industrial sectors that were weak, or even non-existed in the past, including aircraft, automobile, heavy machinery, new machine tools, precision instruments, alloy steel, radio, etc., were built from scratch, thus changing the situation of incomplete Chinese industry and increasing the basic industrial strength. Since then, the industrial system initially formed and industrial value added gradually increased. From 1953 to 1977, China's industrial output increased by 38 times, while heavy industry output value increased by 90 times. Industrial output grew at an average annual rate of $11.3 \%$. (Ma Hong \& Sun Shangqing, 1981). Steel output increased from 1.35 million tons to 31.78 million tons while cement output increased from 2.86 million tons to 62.54 million tons.

Figure 2

Changes of economic structure in the planned economic period

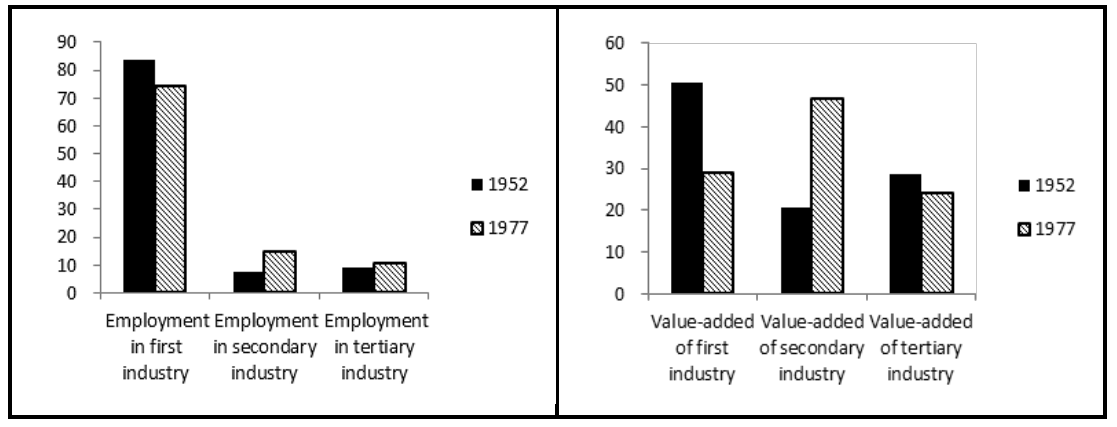

Data source: China statistical yearbook.

As shown in Figure 2, the proportion of industrial value added in GDP increased from $21 \%$ in 1953 to $47 \%$ in 1977 , thus making industrial value added the most important component of GDP. In addition, a significant portion of the agricultural employment population shifted to industry, promoting industrial development.

Before the reform and opening, through the highly centralized development pattern under the planning economy, China quickly completed the necessary 
capital accumulation and effectively developed the industry. Although China was still a large agricultural country, it had initially established the industrial system. Thus, it laid the foundation for the implementation of reform and opening-up policy and economic take-off after 1993. However, the planned economic system also showed some drawbacks in the later period. One of the important manifestations was that this over-emphasis on heavy industry also undermined the efficiency and equity of the economic development ${ }^{2}$. The unbalanced industrial development pattern could not be long-term. The positive effect on the improvement of the economy and people's living standards had been gradually reduced. Therefore, timely exploration of economic reform was vital. Then followed the reform and opening policy.

\section{THE DEVELOPMENT OF THE REFORM AND OPENING POLICY (1979-1992)}

China's achievements and difficulties in planned economy period gave birth to a new era of reform and open. In December 1978, the Third Plenary Session of the Eleventh Central Committee of the CPC was held, which turned out to be a significant turning point of China's economy. It was decided at this meeting that the government should shift the focus to economic development through transforming the system of economic management and expanding economic cooperation with other countries. As a result, China began to implement the reform and opening policy.

After the session reformers began the reform with agriculture in 1978 and extended it to the whole economy, especially industrial and commercial sectors in 1984. Therefore, they created a pattern of economic reform that strongly characterized the period from 1979 through 1992. This phase has become the first stage of reform and opening. During 1979-1992, the basic purpose of the reform was to convert the planned economy to market economy while developing national economy. The government has adopted gradual and decentralizing reforms and the most characteristic feature was the dual-track system which refers to the coexistence of two coordination mechanisms (plan and market) during this period (Barry Naughton, 2007). Chinese government abolished collective farming under the commune ${ }^{3}$ system and adjusted the agricultural policy during this phase. The reform was also undertaken gradually in many areas like price system, state firms and financial sector. Since opening up, the foreign trade has been

\footnotetext{
${ }^{2}$ In the late stage of the planned economy, the efficiency of economic development had declined significantly. China's GDP share of the world continued to decline. The efficiency of capital and labor investment was also declining (Lu Zhoulai, 2009).

${ }^{3}$ The collective farming under the commune is the main features of the rural political and economic system under the planning economy system, is an economic organization of collective ownership of the working masses, perform the "social unity government" system.
} 
expanding due to the fact that the central government's monopoly over foreign trade was relaxed.

In 1979-1992, during which time the economic reform was in practice, the planned economic system began to disintegrate and the market grew. The ownership structure became diverse in this period which was single before reform (Zhao Lingyun, 1999). Market price came to play an important role in the China's economy because of the price decontrol. Consequently, China's economic development has made remarkable achievements.

\subsection{The rapid growth of the national economy}

The reform and opening policy boosted the rapid growth of the national economy. During the first stage of reform and opening (1979-1992), China's GDP increased from RMB367.9 billion in 1978 to RMB2,719.5 billion in 1992 (Figure 1). Although in the late 80s, the driving force of the national economy was insufficient and reform entered hard stage, average annual GDP growth rate in the 1979-1992 period was 9.5\%, reached 11.5\% during 1982-1988.

Since 1978, great changes have taken place in the rural economy. Two new policies were adopted at first. The government increased agricultural procurement prices and adopted the household responsibility system ${ }^{4}$ in agriculture. The success of new policies led to rapid growth of rural economy and changed the situation of grain shortage. Agricultural production grew rapidly at $7.3 \%$ per year during 1979-1984. After that, the Chinese government intensified its efforts to reform the circulation system of agricultural products, readjusted the rural industrial structure and encouraged the development of rural or other nonagricultural industries (Zou Dongtao, 2009).Industrial production grew rapidly at this stage, with Gross value of industrial output increasing from RMB423.7 billion in 1978 to RMB3,459.9 billion at an average annual increase rate of $13.2 \%$. The industrial structure was also revised. The proportion of China's industrial output of light industry increased from $43.1 \%$ in 1978 to $49.4 \%$ in 1990.

\subsection{Diversification of ownership system}

During the early phase of China's reform and opening (1979-1992), diverse ownership structure was created. China's economy began to shift from planned economy to market economy. The dual-track system was the most characteristic feature of China's initial departure from the planned economy (Arthur Sweetman \& Zhang Jun, 2010). It is the golden age of rural industries (TVEs)

\footnotetext{
${ }^{4}$ The household contract responsibility system was an important reform in the rural areas of mainland China in the early 80s, is the basic management mode of collective economy since 1978 in Chinese rural areas.
} 
from 1978. During this period, the state firms were reformed and the non-state sectors rose. The contribution of state firms to China's industrial growth dropped from $82.0 \%$ in 1978 to $32.5 \%$ in 1992, and the status of non-state-owned enterprises in the industrial economy gradually rose.

\subsection{The pattern of opening to the outside world has been beginning to take shape}

China's economy had been a closed economy until the implementation of the opening policy in 1978, which encouraged foreign trade. To be specific, the government established special economic zones (SEZs) and opened coastal areas. SEZs have been authorized to engage in foreign trade and attract FDI. Since then, China has gradually liberalized trade. The total volume of foreign trade amounted to $25 \%$ of its national income in 1987, which was only 7\% in 1978 .

The reform and opening policy is a great choice for China. Compared with the planned economy period, China's comprehensive national strength and forces of production entered a new phase during 1979-1992. In this phase, the exploration of the market economy laid the foundation for the establishment of market economy system in China, which also led to preliminary development of the commodity economy.

\section{THE DEVELOPMENT IN THE ECONOMIC TRANSFORMATION (1993-2001)}

In the early 1990s, during which time China maintained the rapid economic growth and attracted capital all over the world, the income of urban dwellers in China doubled. In 1992, the 14th Party Congress established the goal of reforming socialist market economic system. Thus, in this period, China's Marketization degree gradually deepened, meanwhile, economic efficiency improved, followed by the sustained economic growth. At the same time, the government gave preferential policies of many tangible and intangible benefits to foreign investors to attract investment, thus stimulating economic growth. The China's economic growth pattern switched from consumption-led to investmentled.

\subsection{The rapid expansion of economic aggregate}

In late 1980s, China was at the bottom of a wave of economic fluctuations. In 1991, the economy began to rise (Figure 1). In 1992, China published policies to attract a large number of foreign investments. Direct investment from developed countries greatly promoted China's economic growth ${ }^{5}$. The phenomena of high

\footnotetext{
${ }^{5}$ On one hand, local governments of all levels have long regarded GDP growth and investment scale as an important index to evaluate the performance of local officials, which is achieved by giving a
} 
investment, high money supply, high prices and high imports were further exacerbated. The large-scale inflow of FDI directly led to the rise of GDP in China. After 1993, the economic growth began to slow down, but still maintained a high growth rate of about $9 \%$.

However, after the investment boom, in around 1997, China's actual use of foreign investment declined, impacted by the Asian financial crisis. Weak consumption and shortage of foreign capital led to the economic recession. Commodities became unmarketable, deflation arose and prices began to fall (Cheng Xiaonong, 2000). However, Chinese government adopted prudent financial policy and a series of measures to prevent financial risks, protecting China from direct impact in the crisis. With the reform of state-owned enterprises in 1998 and the turnaround of foreign capital utilization in 2000, China's economy was pulled by both consumption and investment, and began to recover.

\subsection{New economic structure}

In 1993, China's economic structure changed greatly and entered the stage of the development in the economic transformation. The pattern of China's economic growth switched from consumption-led to investment-led ${ }^{6}$. At the same time, with the development of marketization, in 1993, the role that government play in allocation was almost replaced by market, which determined $90 \%$ of the prices. The government gradually withdrew from the market, which is another reflection of economic restructuring (Lu Deming, 1998). The efficiency of the economy rises gradually, which is a key factor in the rapid economic development.

During the early 1990s, China received huge foreign investments. Meanwhile, the National Bank supported poorly operated state-owned sector and resources were reallocated to cities from rural areas. All the three methods ensured rapid economic growth. After the Asian financial crisis in 1997, the government began to encourage state-owned enterprises to cut jobs and salaries, and use the funds to increase efficiency. At the beginning of 1998, the stateowned enterprise began the normalized reform of demutualization (Zhang Liqun, 2001). In 2000, large and medium-sized state-owned enterprises were pulled out of difficulties and started to restructure. The private economy gained more policy support. The policy system for expanding domestic demand was continuously completed. The economic efficiency of enterprises improved. The

\footnotetext{
large number of foreign tangible and intangible concessions to attract foreign investment to stimulate the region's GDP growth; on the other hand, multinational companies in developed countries invested heavily in order to occupy a huge market as soon as possible and enjoy China's cheap or even free labor(Tang Weixia, 2009).

${ }^{6}$ China's consumption and investment rates were $64.5 \%$ and $35.5 \%$ respectively before 1992 , while consumption rates fell sharply after 1993 (Sun Shangqing, 1996).
} 
growth rate of domestic demand increased, along with the recovery of the economy.

\section{THE DEVELOPMENT IN THE UPGRADING INDUSTRY (2001-PRESENT)}

From 1991 to 2001, China has made remarkable progress in the stage of economic transformation and development. Since the beginning of the new century, China's foreign trade has become more and more mature. To join the WTO in 2001 as a symbol, China has entered the stage of economic transformation and upgrading, economic development and reform have made great achievements.

\subsection{Leapfrog development of foreign trade}

Since entering the WTO in 2001, China's foreign trade has presented a leapforward development. In 2001, China's exports amounted to RMB 220.24 billion, accountant for $19.87 \%$ of the GDP of that year, and the growth rate was $6.74 \%$. China's export growth rate increased by 27.39\% during the period from 2002 to 2007, and occupied 30.29\% of GDP on average. By 2007, China's exports reached RMB 935.36 billion and the ratio of exports to GDP was 34.62\%. Before the global financial crisis, China's exports experienced negative growth in 2009, of which the rate was only $-18.29 \%$. However, in 2010, foreign trade exports rebounded strongly, and then continued to grow. The financial crisis forced China to reduce the dependence on export, thus improving the demand structure.

\subsection{National economic achievements}

Along with the development of foreign trade, the national economy is developing rapidly during the period. From 2001 to 2002, the growth rate of GDP and GDP per capita were both about $10 \%$. Since Chinese government set the goal of "complete the building of a well-off society in all respects" in 2002, the national economy has been developing rapidly. In 2007, President Hu put forward the "Scientific Outlook on Development" in a report, and pointed out the vital importance of development and the central position of economic construction. From 2003 to 2008, the growth rates of GDP and per capita GDP growth rate were about $17 \%$, representing the great progress made by national economy. In 2009, before the global financial crisis, the domestic economic development slowed down, growth rate of GDP and per capita GDP fell below $10 \%$. In 2010, the Chinese government launched a large-scale stimulus plan to cushion the impact that the financial crisis exerted on China's economy, leading to the slow growth of GDP and per capita GDP. In 2012, Chinese government stressed that the road of socialism with Chinese characteristics. After that, China's GDP and per capita GDP have become saturated, with the large total 
economy, leading to lower growth rate, which, on the other hand, is also a demonstration of China's economic development entering a new stage.

Industry development showed a good momentum. In 2004, Premier Wen announced at the two sessions that we would gradually reduce the agricultural tax rate, and eventually cancel the agricultural tax in five years. This has greatly contributed to the development of agriculture. From 2001 to 2003, the growth rate of agricultural output was below 5\%, and was even negative in 2003. After 2004, the growth rate increased significantly. The average annual growth rate in 2004-2015 reached 12\%. The high-tech industry is an emerging industrial growth point in China. In the stage of economic transformation and upgrading, under the influence of the third industrial revolution in the world, we need to insist on President Jiang's view that "science and technology is the main embodiment and symbol of advanced productive forces", improve scientific and technological innovation capacity, and vigorously develop high-tech industries. From 2011 to 2015, high-tech industry sales of new products doubled in just four years (from RMB 2247.34 billion to RMB 414.13 billion).

In recent years, China's economy has shown a "new normal" ${ }^{7}$, from highspeed growth to medium-high-speed growth. Economy has been restructuring from factor-driven and investment-driven to innovation-driven, ushering in a new strategic opportunity.

\section{PROSPECTS FOR CHINA'S NEW ECONOMY}

After years of rapid growth, China's economy has entered the New Normal and the economic performs smoothly and progressively. China's steady economic development remained steady, although it is experiencing the pain of the transformation from old to new drivers. With the deepening of China's new industrialization, informatization, urbanization and agricultural modernization, the new economic development accelerated. New industries, new businesses and new models have emerged, and mass entrepreneurship and innovation have been booming. Meanwhile, economic development has shown its great potential, tenacity, as well as wide margin. Nowadays, faced with downward pressure on the economy, The CPC central committee, with comrade Xi Jinping as general secretary, implemented the new development concept, to adapt to the new normal of economic development. It also promoted supply-side structural reform, implemented an innovation-driven strategy, and actively boosted the overall improvement of social productivity.

\footnotetext{
${ }^{7}$ The new normal is different from the past, a relatively stable state, that is a trend irreversible state, means that the Chinese economy has entered a new different stage of rapid growth in the past thirty years, its characteristics are mainly from the rapid growth to medium and high speed growth, the continuous optimization and upgrading of economic structure, as well as from the elements and investment driven into innovation driven.
} 


\subsection{Promoting supply-side structural reform and propelling industrial upgrading}

In recent years, China's economic structure has been continuously optimized, and turned third industry oriented. However, the structural contradictions are still prominent. China's traditional industries are predominant and the problem of overcapacity is obvious. The key to adapting to the new normal is to accelerate restructuring and upgrade the traditional industrial transformation. Supply side structural reform aims to improve the quality of supply, with the reform of the way to promote structural adjustment and correct distortion of factor allocation. The top five priorities are cutting overcapacity, destocking, deleveraging, reducing costs and identifying growth areas.

At the end of 2016, the central economic work conference further stressed that the promotion of supply-side structural reform is a major innovation to adapt to and guide the new normal of economic development. It is an active choice to adapt to the new situation of comprehensive national strength competition faced with the international financial crisis, and is an inevitable requirement of adapting to the new normal of economic development in our country. At the same time, advancing structural reform, especially supply-side structural reform, is a strategic priority of the 13th five-year plan. By moderately expanding aggregate demand, China will focus on the supply-side structural reform, improving both the quality and efficiency of supply system, thus promoting the sustainable economic growth. It also indicates the direction for China's future industrial restructuring and will effectively promote industrial transformation and upgrading.

\subsection{Strengthening innovation, driving development and improving new drivers}

The transformation of the traditional kinetic transformation, as well as new one, is required, especially whilst the traditional kinetic becomes weak, to form a brand new "twin engines" to promote sustained economic growth and the leap to higher levels. Particularly, the emergence of new technique such as Mobile Internet, Big Data, O2O, industry 4.0, New Energy, biological technique, environmental protection and energy saving help to create new economy, new industry, new business format and new pattern, which has had an unprecedented impact on mode of production, mode of life and even the way of thinking. Therefore, in the critical period of the transformation of new and old kinetic energy in China, we must rely on innovation-driven development to foster new growth drivers. On the one hand, science and technology innovation shall play a leading role in the comprehensive innovation. In addition, we should also strengthen the basic research, enhance the original innovation, integrated innovation and the capability of re-innovation after introduction, digestion and absorption, thus improving the capability of independent innovation, providing 
lasting power for the economic and social development. On the other hand, we should integrate the mass entrepreneurship and innovation into all sectors of development as well as encourage all kinds of subjects to develop new technologies, new products, new business format and new modes, thus building a new engine of development.

\subsection{Accelerating the development of new economy and leading the new normal}

At present, China's economy has been operating stably and steadily, and the new economic development has played an important supporting role. In the first half of 2017, for example, the high-tech industry and equipment manufacturing industry developed rapidly, and the output of new energy vehicles increased by 88.7\%, whilst smart TV increased by $20.5 \%$. "Internet plus" accelerated the integration of industry and services, with sales of goods and services on the Internet growing by $28.2 \%$ and delivery services by $55.4 \%$. Not only does new economy subvert the traditional economic system, but also changes or modifies some of the fundamental theorem of economics. With the zero-marginal cost and sharing economy become the norm. It is necessary to replace the traditional theory with innovative thinking and innovation theory so as not to limit the development of new economy.

China is in a critical period of comprehensive upgrading of quality and efficiency. It's necessary to foster new growth points, develop new economy as the driving force for long-term development, and provide lasting support for economic transformation and upgrading. The accelerating development of the new economy is an important thought and development path for China to adapt to and lead the new normal. China will speed up the development of the new economy and promote the release of growth vitality with the main line of supplyside structural reform. At the same time, emerging industries vigorously need promoting and supporting. China ought to consolidate and expand the advantages of China's Internet economy, foster and form other fields such as new energy, new materials, sharing economy, green economy, green finance and other new economic advantages, thus offering possibilities for China's "curve overtaking".

\section{CONCLUSION}

Since the reform and opening, China has been looking for the right way to develop the economy and has made great progress so far. China is among the world's fastest-growing major economy and the national power has increased a lot.

\subsection{The past and the present}

Looking back on the development of China in the past years, we can see that 
China's economy has transformed through successive waves of economic reform. The adoption of "opening-up" policy in 1978 attracted foreign investment to China, turning China from a closed and planning economy into modernized and market economy. Entering the 1990s, China transformed from consumption led economy where the economic growth leans on increasing consumption to investment led economy. Chinese government's control on domestic economy decreased and China economy was surrounded by a more market-oriented environment. After joining WTO in 2001, China gradually merged into the tide of world economic system and global economy integration. In the process of economic transformation and upgrading, through the development in high-tech fields, China's economy was further developed.

Despite the economic depression and the challenges of economic globalization, China has made remarkable progress in economy. Although the economic growth slows down these years, the growth in the past decades is still great, with an average annual growth rate of 9.8\%. Gross domestic product rose from $\$ 216.5$ billion in 1978 to $\$ 11.2$ trillion in 2016. Per capita gross domestic product rose from $\$ 226.3$ in 1978 to $\$ 8126.7$ in 2016 . At the same time, three industries of economy have developed rapidly through structural adjustment. The tertiary industry, with the output rose from $24.6 \%$ of total GDP in 1978 to $51.6 \%$ in 2016, has increasingly become the new engine of the economic growth.

\subsection{The future}

After years of rapid growth, China's economic growth has slowed down and entered a "new normal", featuring slower but higher quality growth. Looking ahead, with the new industrialization, informatization, urbanization and rural modernization, China has huge potential for development. The development of new industry, new forms of business and new business which are driven by innovation will cultivate new growth driver and giving rise to new impetus of the China's economic development. New economy cultivated by new growth driver will become an important part of China's future development. Meanwhile, supply-side structural reforms will advance the restructuring, improve supply structure flexibility, and promote sustained economic and social development.

\section{BIBLIOGRAPHY REFERENCES}

BAI, J F. (2015). "New economy leads the new normal and only the new economy can strengthen China [J]". China Economic Weekly, 14, pp. 22-23.

DEMING, LU (1998). "A comment on China's 20 years economic reform". Journal of Fudan University (SOCIAL SCIENCE EDITION), 5, pp. 11-19+141. 
DONGTAO, ZOU, and RIHUI, OUYANG (2009). New China Economic Development 60 Years: 1949-2009. People's Publishing House.

HONG, MA and SHANGQING, SUN (1981). A Study on China 's Economic Structure [J]. 8(3), pp.26-27.

JIN J. J. and GUO Y. L. (2016). Chinese-style leapfrogging: the new economy leads the new normal [M]. China Renmin University Press.

LINGYUN, ZHAO (2009). "The Endogenous Logic of the Formation, Evolution and Transformation of China's Traditional Planned Economy from 1949 to 2008". Researches in Chinese Economic History, [J], (03), pp. 24-33.

LIQUN, ZHANG (2001). "New features of China's economic growth and its recent development". China Industrial Economics, 8, pp.: 5-11.

LINGYUN, ZHAO (1999). "Transition and friction: 1979-1988 China's economic development process of historical analysis [J]". Contemporary Chinese history research, 1999(1), pp. 48-58.

NAUGHTON, B (2007). "The Chinese Economy: Transitions and Growth [J]". Mit Press Books, 1(4), pp. 511-513.

NATIONAL BUREAU OF STATISTICS (1999). "Comprehensive statistics department of national economy, National Bureau of Statistics. 50 years of new China statistical information" [M]. China Statistics Press, 1999, pp. 95.

SHANGQING, SUN (1996). "Market economy and the development of productivity". Economic Research Journal, 6, pp. 3-8.

SWEETMAN, ARTHUR AND JUN, ZHANG (2010). Economic transformation with Chinese characteristics. Fudan University Press.

THE STATE COUNCIL OF CHINA (2016). Outline of the 13th five-year plan for national economic and social development of the People's Republic of China[EB/OL]. http://www.gov.cn/xinwen/2016-03/17/content_5054992.htm.

THE STATE COUNCIL OF CHINA (2016). "13th Five-Year" National Science and technology innovation planning[EB/OL],http://www.most.gov.cn/mostinfo/xinxifenlei/ gjkjgh/201608/t20160810_127174.htm

THE STATE COUNCIL OF CHINA (2015). Guidance of State Council on promoting "Internet+" action [EB/OL], http://www.gov.cn/zhengce/content/2015-07/04/content_ 10002.htm

WEIXIA, TANG (2009). "Exploring the nature of China's rapid economic growth". Productivity Research, 3, pp. 1-3.

XIAONONG, CHENG (2000). "Where does prosperity come from - Analysis of current situation and trend of economy in China". Open Times 9, pp. 4-24.

ZHOULAI, LU (2009). "On Pre-Reform Efficiency and Equality in China [J]". China Opening Herald, 2009(4), pp. 38-43. 